
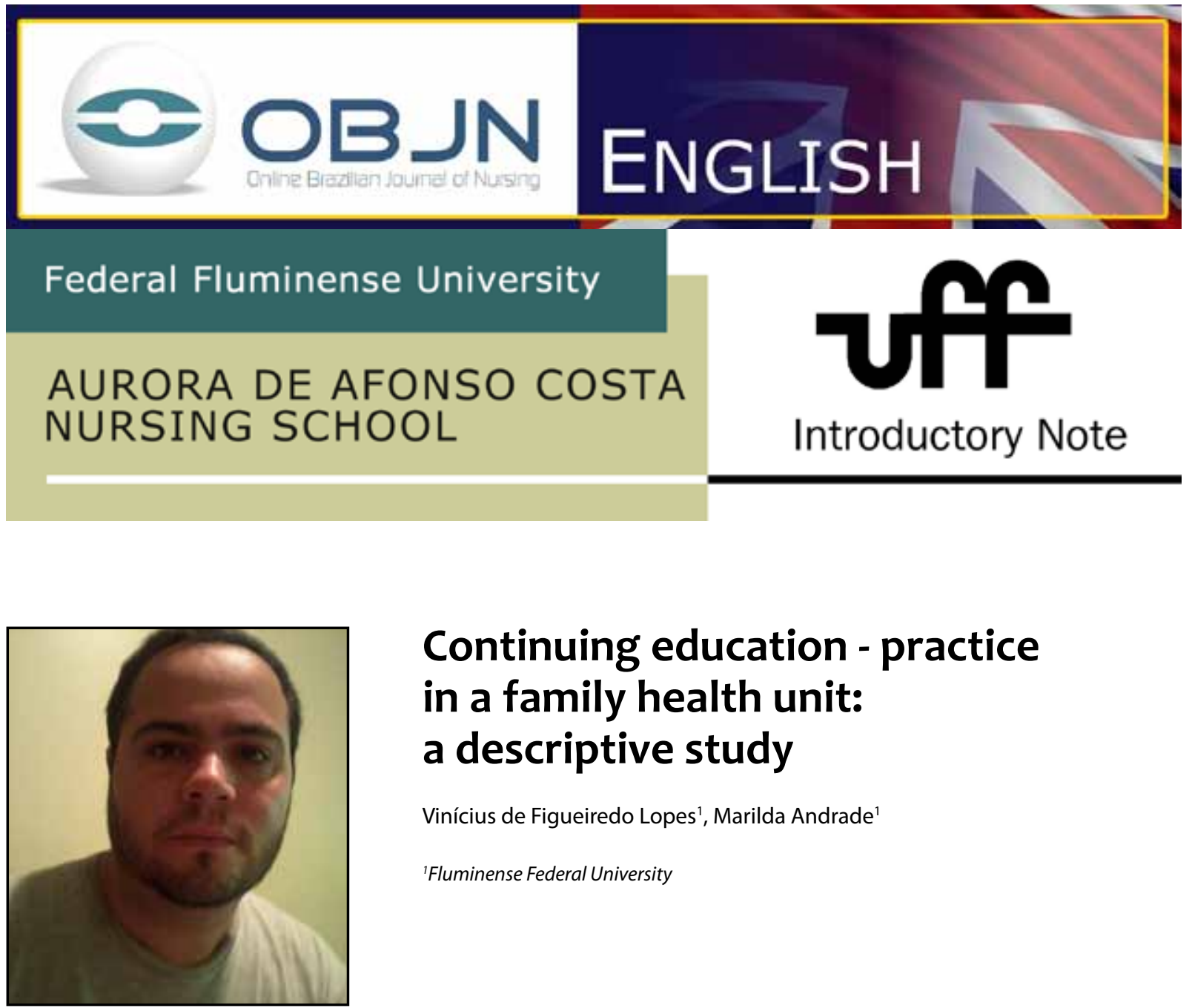

\title{
Continuing education - practice in a family health unit: a descriptive study
}

Vinícius de Figueiredo Lopes ${ }^{1}$, Marilda Andrade

'Fluminense Federal University

\section{ABSTRACT}

Central aim: To know the potentiality of the process of Continuing Health Education (CHE) with regard to family health teams.

Method:This is a descriptive study, in which a qualitative approach is used. For this study we have created an action research proposal. Data will be collected between November 2013 and February 2014 through semistructured interviews. Data will be treated using the analysis of the collective subject discourse as proposed by Lefevre and Lefevre. The subjects will be the health professionals in the family health teams Pillar III, IV and $\mathrm{V}$ of the municipality of Duque de Caxias, RJ. Subsequently, an intervention plan for restructuring the CHE will be developed collectively. It is expected that the study will contribute to improving the $\mathrm{CHE}$ in this location and, therefore, contribute to better healthcare for the user.

Descriptors: Family Health Program; Education, Continuing; Nursing, Education, Health 


\section{PROBLEMATIC SITUATION AND ITS SIGNIFICANCE}

The Family Health Strategy (FHS) was created in 1994 aimed at reorganizing the practice of healthcare. Promotion, prevention, recovery and rehabilitation activities are developed as part of it. The work logic associated with the FHS is based on performance in a specific area, taking the following aspects into consideration: full-time teamwork, community participation, the possibility of inclusion and performance, involving the psycho-affective and social dimensions associated with the practice of new ethics and concerns related to community residents ${ }^{(1)}$.

Educational activities within the FHS are of utmost importance for the development of the work of the professionals involved. Thus, it is necessary to differentiate continuing education (CE) from continuing health education (CHE). Continuing education is characterized by knowledge update, often with a disciplinary perspective, and based on the pedagogy with regard to knowledge transmission. In this model, although individual learning is achieved, it occurs through training that is usually directed to a certain professional category, and includes topics and content chosen vertically ${ }^{(2)}$. CHE seeks alternatives and solutions for real health problems experienced by the sector users. It should be understood as a factor that will influence the process of reflection and transformation of existing practices in the Unified Health System (UHS), so that the professionals involved may face reality by means of the complementation and/or acquisition of new knowledge ${ }^{(3)}$.

The object of this study will be the evaluation and restructuring of the $\mathrm{CHE}$ at the FHS Pillar III, IV and V of the municipality of Duque de Caxias, RJ.

The motivation for the realization of this study emerged from the researcher's trajectory as a nurse in the UHS in the municipality of Duque de Caxias, Rio de Janeiro, where he could witness the difficulty of professionals when it comes to mastering and applying the concept of $\mathrm{CHE}$ over a five year period.

To be healthy, the patient must have access to care activities and services through the work of sensitized and qualified professionals. Therefore, one cannot think of reorganizing the practices of health care without investing in new training policies and the introduction of a continuing process of education with regard to human resources.

\section{GUIDING QUESTION}

How would CHE enhance the work process with regard to family health teams/professionals?

\section{AIMS}

To ascertain the potential of the $\mathrm{CHE}$ process with regard to family health teams; to determine how the $\mathrm{CHE}$ professionals define the FHS; to identify the social and economic profile of FHS professionals; to discuss, in a participatory way, possible facilities and difficulties for the implementation and maintenance of $\mathrm{CHE}$ in the family health teams; to develop an action plan with the participation of FHS professionals, in order to improve the dynamics of the CHE.

\section{ASSUMPTION}

The CHE is a pedagogical strategy that could facilitate the use of transformative actions in local realities, when structured and performed appropriately. Based on this principle, the opti- 
mum structuring and execution of $\mathrm{CHE}$ actions may provide benefits for professionals, the population and the work process.

\section{METHOD}

This is a descriptive study that presents a qualitative approach, and offers an action research proposal. The planned period of data collection is from November 2013 to February 2014, and it will be developed through the analysis of CHE practices performed in the family health teams Pillar III, IV and V of the municipality of Duque de Caxias, RJ. Data will be collected based on two research techniques: a) semi-structured interviews and; b) collective elaboration of an action plan for restructuring of $\mathrm{CHE}$ in the family health units involved.

The population will be composed of 27 health professionals, including doctors, nurses, dentists, nursing technicians, a dental assistant and community health workers. The inclusion criterion is that the professional should work in at least one of the units studied. Those working in the CHE for less than a year will not take part in the study.

The data will be treated through the analysis of the collective subject discourse proposed by Lefevre and Lefevre. The ethical aspects of this project will meet Resolution 466/12 of the National Health Council in relation to the Guidelines and Regulatory Standards of Researches Involving Humans. We obtained approval from the Municipal Secretariat of the city of Duque de Caxias, RJ by means of a consent form with regard to running the study. The proposed study is under consideration by the Ethics Committee and Research of the Antônio Pedro Hospital.

\section{REFERENCES}

1. Costa V, Cezar-Vaz MR, Cardoso L, Soarez JF. Educação permanente no Programa Saúde da Família: um estudo qualitativo. Invest educ enferm. 2010; 28(3):336-44.

2. Godinho JSL, Tavares CMM. The Permanent Education in Intensive Care Units: a review article. Online braz j nurs [Internet]. 2009 June [Cited 2013 Aug 26]; 8 (2): [about 3 p.]. Available from:http://www.objnursing.uff.br/index.php/ nursing/article/view/2288. doi: http://dx.doi. org/10.5935/1676-4285.20092288

3. Sardinha PL, Cuzatis GL, Dutra DCT, Tavares CMDM, Dantas CAC, Antunes CE. Educação permanente, continuada e em serviço: desvendando seus conceitos. Enferm glob [Internet]. 2013 [cited 2013 Ago 23]; 12(29):307-22. Available from: http://scielo.isciii.es/scielo.php?script=sci_arttex t\&pid=S169561412013000100017\&lng=es

\section{Project Data}

Dissertation project of the Master's Professional Program in Health Education of the UFF.

Advisor: Marilda Andrade

Received: $24 / 08 / 2013$

Revised: 10/09/2013

Approved: 12/09/2013 